\title{
GAMBARAN PENGELOLAAN SAMPAH RUMAH TANGGA DI KABUPATEN KUDUS TAHUN 2016: STUDI EHRA I
}

\author{
Rusdin Rauf ${ }^{1}$, Nurdiana ${ }^{2}$, Maryata $^{3}$, Rusiyati ${ }^{4}$, Suwandi $^{5}$ \\ ${ }^{1,2}$ Fakultas Ilmu Kesehatan, Universitas Muhammadiyah Surakarta, Jl. Ahmad Yani, \\ Pabelan, Kartasura, Surakarta. Email: ${ }^{1}$ rusdin.rauf@ums.ac.id, \\ 2nurdiana.9886@gmail.com \\ 3,4,5 Dinas Kesehatan Kabupaten Kudus, Jl. Diponegoro No. 15, Kota Kudus. \\ Email: ${ }^{3}$ maryatakudus@gmail.com, ${ }^{4}$ rosi.rusiyati@ymail.com, \\ ${ }^{5}$ suwandirangga@yahoo.co.id
}

\begin{abstract}
ABSTRAK
Studi Penilaian Risiko Kesehatan Lingkungan (Environmental Health Risk Assessment = EHRA) adalah sebuah studi partisipatif di Kabupaten/Kota untuk memahami kondisi fasilitas sanitasi dan higiene serta perilaku-perilaku masyarakat pada skala rumah tangga. Penelitian ini bertujuan untuk memberikan gambaran terkait pengelolaan sampah rumah tangga di Kabupaten Kudus. Penelitian ini menggunakan pendekatan kuantitatif, dengan teknik pengumpulan data yaitu wawancara. Pengumpulan data dilakukan oleh enumerator yang terseleksi. Desa/Kelurahan yang menjadi area studi ditentukan secara stratified random. Responden dari setiap area studi, ditentukan secara random. Hasil penelitian menunjukkan bahwa di Kabupaten Kudus, hanya 32,6\% responden (sebanyak 300 dari 920 responden) yang melakukan pengumpulan sampah untuk dibuang ke TPS atau dikumpulkan oleh kolektor informal pada cluster 1, 2 dan 3 . Sedangkan responden pada cluster 0, tidak melakukan pengumpulan sampah. Responden yang melakukan pemilahan sampah sebelum dibuang, hanya sebanyak $2,3 \%$.
\end{abstract}

Kata Kunci: EHRA, Kabupaten Kudus,sanitasi, sampah.

\begin{abstract}
Environmental Health Risk Assessment (EHRA) study is a participatory study in the District / City to understand the conditions of sanitation facilities and hygiene as well as societal attitudes at the household scale. This purpose of the study was to provide an overview related to the management of household waste in Kudus. A quantitative approach was used, with interview in data collection. Data were collected by selected enumerators.The Villages of the study area were determined by stratified random. Respondents from each only $32.6 \%$ of respondents (as many as 300 of the 920 respondents) were collecting waste to be thrown to the polls or collected by informal collectors in cluster 1,2 and 3 , while respondents in cluster 0 did not performwaste collection. A $2.3 \%$ of respondents who were sort the waste before disposal.
\end{abstract}

Keywords: EHRA, Kudus, sanitation, waste. 


\section{PENDAHULUAN}

Sampah merupakan salah satu masalah yang dihadapi perkotaan di semua negara, termasuk Indonesia. Bahkan, dilaporkan oleh Jambeck dkk (2015) bahwa Indonesia termasuk salah satu dari 20 negara penyumbang sampah plastik terbesar di dunia yang mencemari lautan. Namun, menurut laporan Kementrian Lingkungan Hidup (2008), sebagian besar sampah di Indonesia berupa sampah organik, yaitu $58 \%$. Kemudian diikuti oleh sampah plastik sebanyak $14 \%$ dan kertas sebanyak $9 \%$. Lebih lanjut dilaporkan bahwa sebagian besar sampah padat berasal dari rumah tangga.

Berbagai studi telah melaporkan upaya untuk mengatasi masalah sampah padat dari rumah tangga. Sampah padat dari rumah tangga perlu difokuskan penanganannya karena merupakan sumber utama penyumbang sampah padat diperkotaan. Kardono (2007) melaporkan bahwa setiap tahun di Indonesia, terjadi peningkatan volume sampah sebanyak 2 $4 \%$. Selain itu, adanya variasi komposisi dari sampah padat rumah tangga, membutuhkan penanganan yang berbeda. Sampah organik dan sampah inorganik memiliki karakteristik yang berbeda, sehingga membutuhkan penanganan yang berbeda.

Perbedaan teknik penanganan sampah yang didasarkan pada keunikan karakteristik setiap janis sampah, yaitu organik dan inorganik, sehingga membutuhkan suatu sistem manajemen atau pengelolaan sampah padat. Manajemen sampah padat merupakan suatu sistem menangani sampah padat, mulai dari pengumpulan, penyimpanan, pengolahan dan pembuangan (Chalam dkk, 2009). Berbagai faktor memberikan pengaruh terhadap upaya mengoptimalkan keberhasilan manajemen sampah padat rumah tangga. Terdapat beberapa faktor, yang diterima secara Internasional, yang memberikan pengaruh terhadap keberhasilan penanganan sampah, yaitu atribut sosio-demografi, situasi dan kondisi lingkungan, sikap individu terhadap penanganan sampah, norma personal, norma sosial, informasi dan pengetahuan, serta persepsi individu (Vitor dan Martinho, 2016).

Golongan masyarakat yang cukup penting peranannya dalam sistem manajemen sampah adalah anggota rumah tangga. Aprilia dkk (2012) menjelaskan bahwa rumah tangga berperan penting dalam sistem manajemen sampah padat. Kardono (2007) menjelaskan bahwa salah satu sistem manajemen pengelolaan sampah yang saat ini dianggap sebagai yang terbaik adalah sistem manajemen sampah terintergarasi atau Integrated Solid Waste Management (ISWM), yang penerapannya berbasis rumah tangga, sehingga membutuhkan partisipasi dari rumah tangga.

Secara teknis, ISWM mengombinasikan berbagai teknologi, seperti penyortasian, pengomposan, daur ulang, pembakaran, dan penimbunan, yang diterapkan dan diadaptasikan dengan situasi dan kondisi lokal. Penerapan ISWM di Indonesia dapat mengurangi sebanyak $18 \%$ sampah padat (Kardono, 2007). Keberhasilan dalam menerapkan sistem ini, sangat tergantung pada pengetahuan (Chung dan Lo, 2008) dan sikap masyarakat terkait pengelolaan sampah (Zhuang dkk, 2008). Pemahaman terhadap pengetahuan dan sikap rumah tangga terhadap sistem manajemen sampah padat merupakan langkah awal dalam upaya menerapkan ISWM di wilayah perkotaan di Indonesia.

Studi Penilaian Risiko Kesehatan Lingkungan (Environmental Health Risk Assessment $=$ EHRA) adalah sebuah studi partisipatif di Kabupaten/Kota untuk memahami kondisi fasilitas sanitasi dan higinitas serta perilaku-perilaku masyarakat pada skala rumah tangga. Data 
yang dihasilkan dapat dimanfaatkan untuk pengembangan program sanitasi termasuk advokasi di kabupaten/kota sampai dengan kelurahan (USDP, 2014). Tujuan dari penelitian ini adalah memberikan gambaran terkait pengelolaan sampah rumah tangga di Kabupaten Kudus.

\section{METODE PENELITIAN}

Penelitian ini menggunakan pendekatan kuantitatif, dengan teknik pengumpulan data yaitu wawancara. Pengumpulan data dilakukan oleh enumerator yang terseleksi. Selain itu, juga diseleksi supervisor lapangan, yang bertugas mengawasi pelaksanaan pengumpulan data oleh enumerator. Enumerator dan supervisor, sebelum melaksanakan tugas survei, terlebih dahulu mengikuti pelatihan, dengan materi yang mencakup dasar-dasar wawancara dan pengamatan, pemahaman tentang instrumen EHRA, latar belakang konseptual dan praktis tentang indikatorindikator, uji coba lapangan dan diskusi instrumen.

\section{Penentuan Target Area Survei}

Penentuan Desa/Kelurahan yang menjadi target area survei, mempertimbangkan kondisi geografi dan demografi melalui proses clustering. Proses clustering ini, dilakukan melalui Stratifikasi Desa/Kelurahan di Kabupaten/Kota, sehingga menghasilkan Cluster/Tingkatan Risiko Kesehatan
Lingkungan dari Desa/Kelurahan. Desa/Kelurahan yang terdapat pada Cluster tertentu yang sama, dianggap memiliki tingkat risiko kesehatan lingkungan yang sama. Dengan demikian, Desa/Kelurahan yang menjadi Area Studi pada suatu Cluster, mewakili Desa/Kelurahan lainnya yang bukan merupakan Area Studi pada Cluster yang sama.

Penetapan Cluster dilakukan berdasarkan 4 (empat) kriteria utama yang sudah ditetapkan oleh Program PPSP dan wajib digunakan oleh semua Pokja Sanitasi Kabupaten/Kota dalam melakukan Studi EHRA. Kriteria utama penetapan Cluster tersebut adalah sebagai berikut :

a. Kepadatan penduduk yaitu jumlah penduduk per luas wilayah tertentu. Data kepadatan penduduk diperoleh dari Badan Pusat Statistik Kabupaten Kudus. Desa/Kelurahan dinyatakan padat apabila kepadatan penduduknya lebih dari 25 jiwa per Ha.

b. Angka kemiskinan dengan indikator yang datanya mudah diperoleh tapi cukup representatif menunjukkan kondisi sosial ekonomi setiap desa/kelurahan. Angka kemisikinan di Kabupaten Kudus dihitung berdasarkan proporsi jumlah keluarga pra sejahtera dan keluarga sejahtera 1 sesuai dengan BPS (2015), dengan formula sebagai berikut :

$$
\text { Angka Kemiskinan }=\frac{(\Sigma \text { Pra-KS }+\Sigma \mathrm{KS} 1)}{\Sigma \mathrm{KK}}
$$

c. Daerah/wilayah yang dialiri sungai/saluran drainase/ saluran irigasi yang berpotensi digunakan atau telah digunakan sebagai sarana MCK dan pembuangan sampah oleh masyarakat setempat.

d. Daerah terkena banjir dan dinilai mengangggu ketentraman masyarakat dengan parameter ketinggian air, luas daerah banjir/genangan, dan lamanya surut yang bisa ditentukan oleh Pokja atau mengacu kepada SPM PU dengan ketinggian genangan lebih dari $30 \mathrm{~cm}$ 
dan lamanya genangan lebih dari 2 jam.
Berdasarkan kriteria penetapan cluster tersebut, dibuat kategori cluster, yang ditampilkan pada Tabel 1 .

Tabel 1. Kategori Cluster dan Kriteria Desa/Kelurahan untuk Studi EHRA

\begin{tabular}{cl}
\hline Katagori Cluster & \multicolumn{1}{c}{ Kriteria } \\
\hline Cluster 0 & $\begin{array}{l}\text { Wilayah desa/kelurahan yang tidak memenuhi sama sekali kriteria indikasi } \\
\text { lingkungan berisiko }\end{array}$ \\
Cluster 1 & $\begin{array}{l}\text { Wilayah desa/kelurahan yang memenuhi minimal 1 kriteria indikasi lingkungan } \\
\text { berisiko }\end{array}$ \\
Cluster 2 & $\begin{array}{l}\text { Wilayah desa/kelurahan yang memenuhi minimal 2 kriteria indikasi lingkungan } \\
\text { berisiko } \\
\text { Wilayah desa/kelurahan yang memenuhi minimal 3 kriteria indikasi lingkungan } \\
\text { berisiko }\end{array}$ \\
\hline Cluster 4 & $\begin{array}{l}\text { Wilayah desa/kelurahan yang memenuhi minimal } 4 \text { kriteria indikasi lingkungan } \\
\text { berisiko }\end{array}$ \\
\hline
\end{tabular}

Penentuan Unit Sampling dan merepresentasikan populasi rumah tangga Responden di kabupaten Kudus. Penentuan jumlah

Survei yang dilakukan untuk responden dalam survei ini didasarkan mendapatkan gambaran situasi sanitasi di pada "Rumus Slovin", seperti yang Kabupaten Kudus, dilakukan dengan diberikan oleh Serakan (1992) yang pengambilan sampel yang memenuhi disitasi oleh Dionco-Adetayo (2011), syarat secara statistik, sehingga dapat yaitu:

Diketehui:

$$
\mathrm{n}=\mathrm{N} /\left(\mathrm{N} \cdot \mathrm{d}^{2}+1\right)
$$

Populasi rumah tangga $(\mathrm{N})=204.791$ (BPS Kabupaten Kudus, 2015) Sehingga:

Tingkat kepercayaan $(\mathrm{d})=95 \%(0,05)$

$$
\begin{aligned}
\mathrm{n} & =204791 /\left(204791 \times 0,05^{2}+1\right) \\
& =513 \text { rumah tangga }
\end{aligned}
$$

Jumlah minimum responden menurut Rumus Slovin adalah sebanyak 513. Namun, dengan mempertimbangkan bahwa setiap Desa/Kelurahan terdiri atas minimal 8 RT, dan setiap RT terdiri atas minimal 5 responden, serta keterwakilan setiap Kecamatan dalam studi, maka ditetapkan bahwa jumlah Desa/Kelurahan yang dijadikan studi EHRA sebanyak 23 Desa/Kelurahan, dengan jumlah responden sebanyak 920 rumah tangga.

Unit sampling utama dari studi ini adalah RT (Rukun Tetangga) yang mewakili semua Kecamatan di Kabupaten
Kudus. RT yang menjadi target studi dipilih secara random di setiap Desa/Kelurahan yang telah ditentukan menjadi area survei.Jumlah sampel per Desa/Kelurahan adalah 40 responden. Jumlah RT untuk setiap desa/kelurahan yang menjadi area survei sebanyak 8 RT. Jumlah responden untuk setiap RT sebanyak 5 responden. Yang menjadi responden adalah ibu atau anak perempuan yang sudah menikah dan berumur antara $18 \mathrm{~s} / \mathrm{d} 60$ tahun. 
Penentuan Desa/Kelurahan Lokasi Survei

Desa/Kelurahan yang dijadikan area studi mewakili semua Kecamatan di Kabupaten Kudus. Setiap Kecamatan diseleksi 2 sampai 3 Desa/Kelurahan sebagai area studi, dengan mempertimbangkan jumlah Desa/Kelurahan dari setiap Kecamatan. Desa/Kelurahan yang menjadi area studi ditetapkan secara stratified, yang didasarkan pada 5 cluster (cluster 0 sampai cluster 4) yaitu kepadatan penduduk, kemiskinan, DAS dan area banjir.

Setelah semua Desa/Kelurahan didistribusikan pada setiap cluster, kemudian dilakukan penentuan jumlah Desa/Kelurahan yang menjadi lokasi survei, dengan cara menghitung terlebih dahulu proporsi jumlah Desa/Kelurahan yang dapat ditetapkan dari setiap cluster. Setiap cluster dipilih dan diwakilkan Desa/Kelurahan sebanyak $20 \%$. Distribusi Kecamatan dan desa/Kelurahan yang terpilih sebagai area survei EHRA disajikan pada Tabel 2.

Tabel 2. Distribusi Kecamatan dan Desa/Kelurahan yang terpilih sebagai area survei EHRA di Kabupaten Kudus.

\begin{tabular}{|c|c|c|c|c|c|}
\hline No. & Cluster & Kecamatan & Desa/Kelurahan & Jumlah RT & Responden \\
\hline 1 & 3 & Jati & Ngembal Kulon & 8 & 40 \\
\hline 2 & 3 & Undaan & Undaan Lor & 8 & 40 \\
\hline 3 & 3 & Mejobo & Mejobo & 8 & 40 \\
\hline 4 & 3 & Jekulo & Bulungcangkring & 8 & 40 \\
\hline 5 & 2 & Kaliwungu & Prambatan Lor & 8 & 40 \\
\hline 6 & 2 & Kota & Wergu Wetan & 8 & 40 \\
\hline 7 & 2 & Jati & Jati Kulon & 8 & 40 \\
\hline 8 & 2 & Jati & Pasuruhan Lor & 8 & 40 \\
\hline 9 & 2 & Undaan & Medini & 8 & 40 \\
\hline 10 & 2 & Undaan & Larikrejo & 8 & 40 \\
\hline 11 & 2 & Mejobo & Payaman & 8 & 40 \\
\hline 12 & 2 & Jekulo & Gondoharum & 8 & 40 \\
\hline 13 & 2 & $\mathrm{Bae}$ & Bacin & 8 & 40 \\
\hline 14 & 2 & Dawe & Kandangmas & 8 & 40 \\
\hline 15 & 2 & Dawe & Kajar & 8 & 40 \\
\hline 16 & 2 & Dawe & Glagah Kulon & 8 & 40 \\
\hline 17 & 1 & Kaliwungu & Gamong & 8 & 40 \\
\hline 18 & 1 & Kaliwungu & Setrokalangan & 8 & 40 \\
\hline 19 & 1 & Kota & Janggalan & 8 & 40 \\
\hline 20 & 1 & Kota & Sunggingan & 8 & 40 \\
\hline 21 & 1 & Bae & Gondangmanis & 8 & 40 \\
\hline 22 & 0 & Gebog & Kedungsari & 8 & 40 \\
\hline 23 & 0 & Gebog & Rahtawu & 8 & 40 \\
\hline \multicolumn{2}{|c|}{ Jumlah } & 9 & 23 & 184 & 920 \\
\hline
\end{tabular}

Berdasarkan Tabel 2, pembagian cluster Desa/Kelurahan di Kabupaten Kudus, hanya terpenuhi empat cluster, yaitu cluster 0 , cluster 1 , cluster 2 dan cluster 3. Artinya, tidak teridentifikasi Desa/kelurahan yang termasuk dalam Kategori cluster 4, yang memenuhi semua indikator, yaitu kepadatan penduduk, kemiskinan, DAS, dan area banjir.

\section{Penentuan RT dan Responden di Lokasi Survei}

RT dan responden rumah tangga dari setiap Desa/Kelurahan lokasi survei, dipilih secara acak (random sampling). Penentuan RT dan responden dilakukan secara acak, dengan tahapan sebagai berikut: 
a) Jumlah responden per desa/kelurahan sebanyak 40 responden dibagi dengan Jumlah RT yang ada pada desa/kelurahan terpilih.

b) Buat daftar rumah tangga berdasarkan pengamatan keliling pada RT di desa/kelurahan tersebut.

c) Tentukan Angka Interval (AI) dengan cara sebagai berikut :

- Jumlah Total KK per RT pada

Desa/kelurahan terpilih $=\mathrm{X}$

- Jumlah responden yang diambil pada $\mathrm{RT}$ tersebut $=\mathrm{Y}$

- Angka Interval (AI) = Jumlah Total KK per RT / Jumlah responden per RT

$\mathrm{AI}=\mathrm{X} / \mathrm{Y}$ (Pembulatan keatas)

d) Untuk menentukan responden pertama diambil secara acak angka
1 - AI yang dimulai dari rumah

Ketua RT.

e) Rumah selanjutnya diambil sesuai angka interval pada RT tersebut dengan putaran searah jarum jam.

Terus berputar sesuai dengan angka interval sampai mendapatkan jumlah responden yang diambil pada RT tersebut (Y).

\section{HASIL DAN PEMBAHASAN \\ Informasi Responden}

Informasi responden dalam studi EHRA di Kabupaten Kudus, diuraikan menurut kelompok umur, status rumah yang ditempati, pendidikan, kepemilikan surat keterangan tidak mampu, kepemilikan kartu asuransi kesehatan bagi keluarga miskin, dan kepemilikan anak. Data informasi responden disajikan pada Tabel 3.

Tabel 3. Informasi Responden Studi EHRA di Kabupaten Kudus

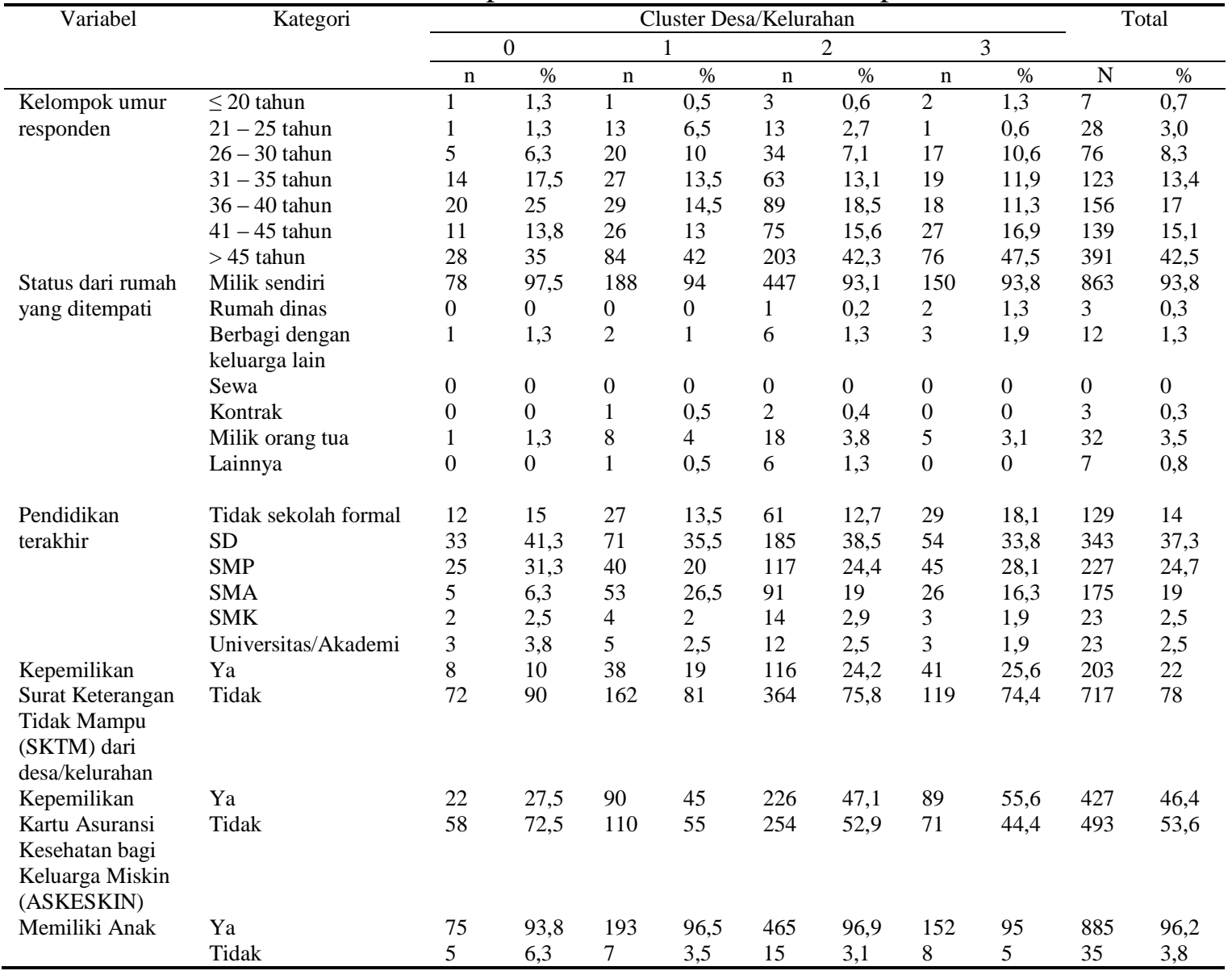


Umur responden dalam studi EHRA di Kabupaten Kudus yang diberikan pada Tabel 3, terdistribusi pada semua kategori umur. Persentase responden dari setiap kategori menunjukkan nilai yang berbeda. Kategori umur $>45$ tahun menunjukkan persentase responden tertinggi, yaitu 42,5 $\%$, yang diikuti oleh kategori umur 36-40 tahun, yaitu $17 \%$. Sedangkan responden dengan kategori umur $\leq 20$ tahun memberikan persentase responden yang paling rendah, yaitu $0,7 \%$.

Status rumah responden studi EHRA sebagian besar merupakan milik sendiri, yaitu sebanyak 93,8 \%. Kepemilikan rumah sendiri terdistribusi merata di seluruh cluster Desa/Kelurahan. Pada studi ini, tidak ditemukan adanya responden yang status rumahnya sewa. Dari data tersebut, menunjukkan bahwa sebanyak $6,2 \%$ responden menempati rumah yang bukan milik sendiri. Konsekuensi dari kondisi tersebut adalah pada ketersediaan fasilitas sanitasi rumah tangga. Responden yang tidak menempati rumah sendiri cenderung tidak dapat menyesuaikan fasilitas sanitasi di rumah dengan kebutuhannya.

Tingkat pendidikan merupakan faktor yang sangat menentukan pengetahuan, sikap dan praktek sanitasi dalam rumah tangga. Tingkat pendidikan responden dari studi EHRA sebagian besar adalah Sekolah Dasar. Tingkat pendidikan SMK dan Universitas/Akademi memberikan porsi terendah, yaitu masing-masing sebanyak
$2,5 \%$. Baik tingkat pendidikan Sekolah Dasar maupun Universitas/Akademi, Desa/Kelurahan pada cluster 0 menunjukkan porsi yang paling tinggi. Menurut Riswan dkk (2011) tingkat pendidikan memiliki korelasi positif dengan pengelolaan sampah rumah tangga.

Kepemilikan Surat Keterangan Tidak Mampu (SKTM) dari responden, cukup rendah, yaitu $22 \%$. Dari jumlah tersebut, cluster 3 menunjukkan porsi paling tinggi. Diikuti cluster 2, cluster 1, dan yang paling rendah adalah cluster 0 . Kecenderungan yang sama diberikan oleh kepemilikan ASKESKIN, dengan jumlah kepemilikan tertinggi yaitu cluster 3 dan yang terendah adalah cluster 0 . Secara umum, kepemilikan ASKESKIN sebanyak $46,4 \%$.

Sebagian besar responden dari studi EHRA, memiliki anak, yaitu 96,2 \%. Jumlah tersebut terdistribusi merata di semua cluster Desa/Kelurahan.

\section{Pengelolaan Sampah Rumah Tangga}

a. Kondisi Sampah di Lingkungan

Kondisi sampah yang pengelolaannya kurang baik di lingkungan RT/RW menurut responden, menunjukkan bahwa secara umum, Desa/Kelurahan yang berada pada cluster 0 memberikan porsi yang paling tinggi. Kondisi yang paling rendah diberikan oleh cluster 1.Kondisi sampah di lingkungan menurut responden, ditampilkan pada Gambar 1. 


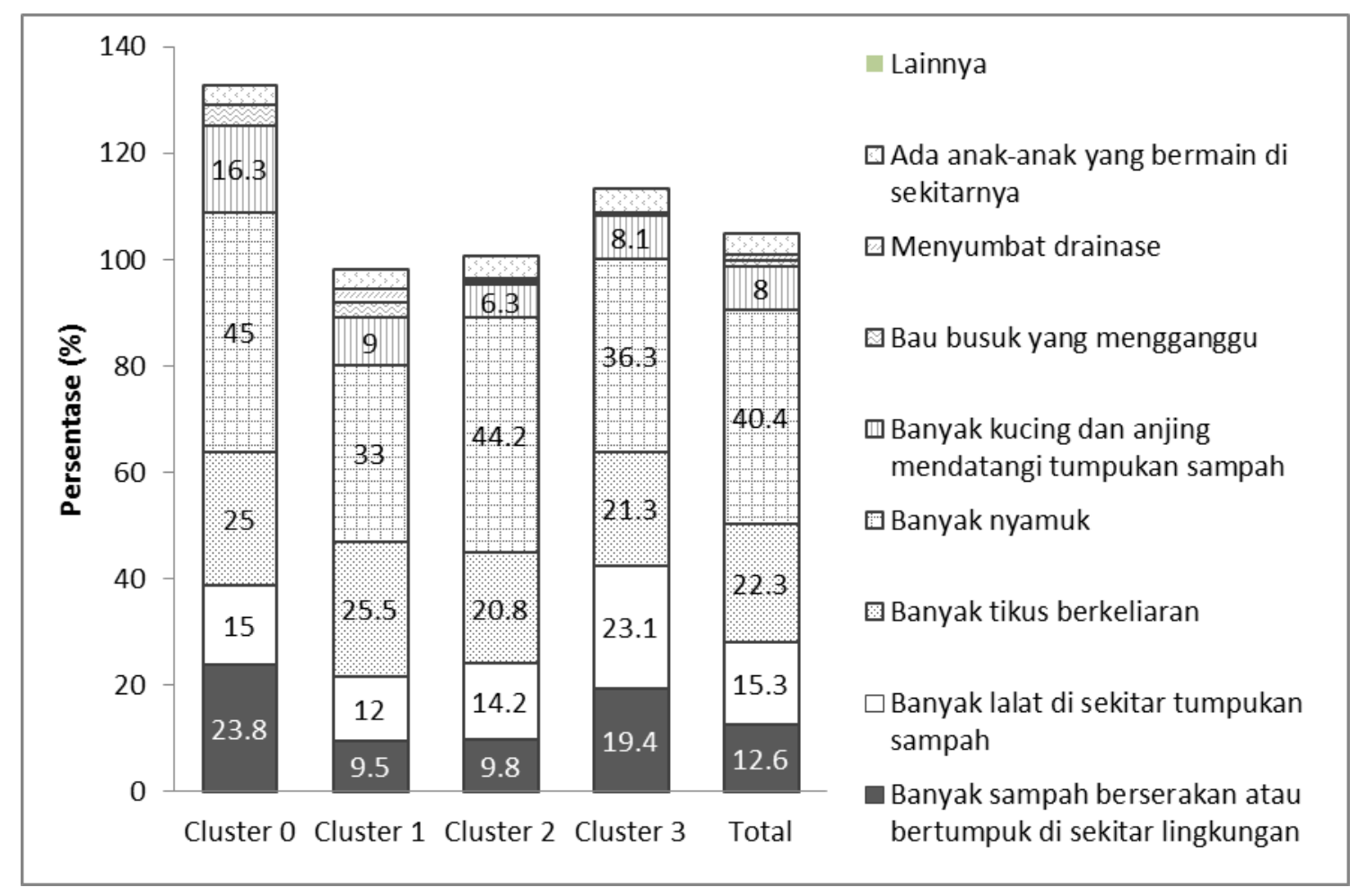

Gambar 1. Grafik Kondisi Sampah di Lingkungan RT/RW

Secara total, indikator tertinggi diberikan oleh "banyaknya nyamuk", yaitu $40,4 \%$. Selanjutnya diikuti oleh indikator "banyaknya tikus yang berkeliaran, banyaknya lalat dan banyaknya sampah berserakan atau bertumpuk di lingkungan".

Persentase responden yang menyatakan banyaknya nyamuk di lingkungan, diberikan oleh cluster 0 , diikuti oleh cluster 2 , yaitu masing-masing $45 \%$ dan $44,2 \%$. Banyaknya tikus yang berkeliaran, sebagian besar dinyatakan pada cluster 2 , diikuti oleh cluster 0 , yaitu masing-masing sebesar 25,5\% dan $25 \%$. Untuk banyaknya lalat disekitar tumpukan sampah, yang paling besar ditampilkan pada cluster3, yaitu 23,1\%. Banyaknya sampah yang berserakan di lingkungan RT/RW menurut responden, sebagian besar berada pada cluster 0 , yaitu $23,8 \%$, sedangkan yang terendah diberikan oleh cluster 1, yaitu $9,5 \%$. b. Pengelolaan Sampah Rumah Tangga

Atalia dkk (2015) melaporkan bahwa sampah organik dari rumah tangga, mudah mengalami dekomposisi, sehingga penanganannya dapat dilakukan dengan proses pembuatan kompos yang melibatkan mikroorganisme. Sedangkan sampah inorganik seperti plastik dan kertas dapat dilakukan proses daur ulang.

Pengelolaan sampah rumah tangga di Kabupaten Kudus menurut responden, sebagian besar dibakar, yaitu57,2 \%. Selain itu, sebanyak $19,7 \%$ responden menyatakan bahwa sampah dikumpulkan dan dibuang ke TPS. Sedangkan sampah yang dikumpulkan oleh kolektor informal, sebesar $12,9 \%$. Secara total, aktivitas pengumpulan sampah hanya dilakukan sebanyak 32,6\% atau 300 responden. Gambaran pengelolaan sampah rumah tangga di Kabupaten Kudus, diberikan pada Gambar 2. 


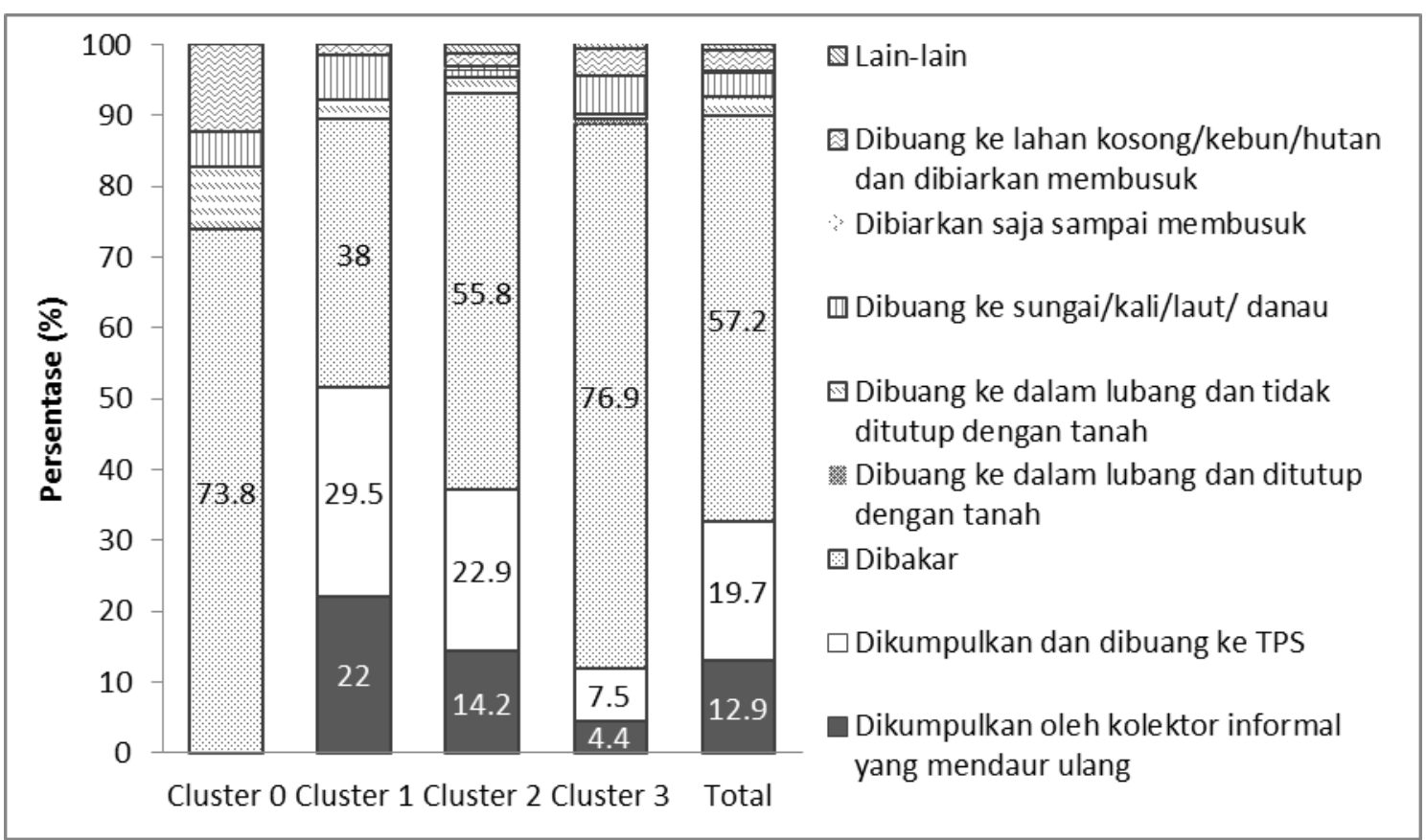

Gambar 2. Grafik Pengelolaan Sampah Rumah Tangga

Responden yang membakar sampah rumah tangga sebagian besar terdapat pada cluster 3, yaitu 76,9\% (Gambar 2), yang diikuti oleh cluster 0 , yaitu $73,8 \%$. Sampah yang dikumpulkan dan dibuang ke TPS, sebagian besar dinyatakan oleh responden pada cluster 1 , yaitu sebanyak $29,5 \%$. Untuk responden pada cluster 0 , Tidak mengumpulkan dan membuang sampah ke TPS. Sampah yang dikumpulkan oleh kolektor, sebagian besar dilaksanakan pada cluster 1 . Untuk responden pada cluster 0 , tidak terdapat aktivitas pengumpulan sampah oleh kolektor informal. Sebagian besar responden pada cluster 3 melakukan pembakaran sampah.

Tingginya persentase responden yang membakar sampah menunjukkan bahwa masih banyak responden yang belum menerapkan sistem pengelolaan sampah dengan baik. Guerrero dkk (2013) menyatakan bahwa keberhasilan manajemen sampah dipengaruhi oleh berbagai faktor yang dapat menunjang sistem manajeman, yaitu lingkungan, teknis, finansial, sosio-budaya, institusional dan legal. Tampak bahwa faktor yang sangat dominan sebagai penentu keberhasilan pengelolaan sampah adalah mayarakat atau personal.

Upaya pengelolaan sampah padat rumah tangga perlu segera dilakukan, mengingat ancaman banjir yang dapat diperparah oleh timbunan sampah yang menutupi selokan dan saluran air. Tobing (2005) menjelaskan bahwa sampah padat, baik yang masih segar maupun yang sudah membusuk, yang terbawa masuk ke got/selokan dan sungai, dapat menghambat aliran air dan memperdangkal sungai. Pendangkalan menyebabkan kapasitas sungai berkurang, sehingga air menjadi tergenang dan meluap menyebabkan banjir.

c. Pemilahan Sampah di Rumah

Salah satu unsur teknis dalam sistem pengelolaan sampah terintegrasi adalah pemilahan sampah.Responden yang sampahnya "dikumpulkan oleh kolektor informal" serta yang 
"dikumpulkan dan dibuang ke TPS", menyatakan melakukan pemilahan dilakukan evaluasi apakah mereka sampah di rumah. Artinya, hanya 7 dari melakukan pemilahan sampah terlebih 920 responden yang melakukan pemilahan dahulu sebelum dikumpulkan dan dibuang sampah sebelum dibuang. Data kegiatan ke TPS. Secara total, hanya sebanyak 2,3 pemilahan sampah disajikan pada Gambar $\%$ dari total responden tersebut yang 3 .



Gambar 3. Grafik Kegiatan Pemilahan Sampah di Rumah

Gambar 3 dapat dijelaskan bahwacluster 3 menunjukkan persentase responden terbesar yang melakukan pemilahan sampah di rumah sebelum dibuang. Responden pada cluster 0 tampak tidak ada yang melakukan kegiatan pemilahan sampah. Hal ini karena di Desa/Kelurahan cluster 0 tidak terdapat kegiatan pengumpulan sampah untuk dibuang ke TPS, maupun pengumpulan sampah oleh kolektor informal.

Rendahnya partisipasi rumah tangga dalam pemilahan sampah, menurut
Sujauddin dkk (2008) disebabkan oleh rendahnya tingkat pendidikan, rendahnya pendapatan dan jumlah anggota keluarga.

d. Frekuensi Petugas Mengangkut Sampah Beberapa responden melakukan aktivitas pengumpulan sampah rumah tangga. Sampah yang telah dikumpulkan tersebut, selanjutnya akan diangkut oleh petugas untuk dibawa ke TPS. Pengangkutan sampah di Kabupaten Kudus oleh petugas, yang ditampilkan pada Gambar 4, menunjukkan frekuensi yang berbeda. 


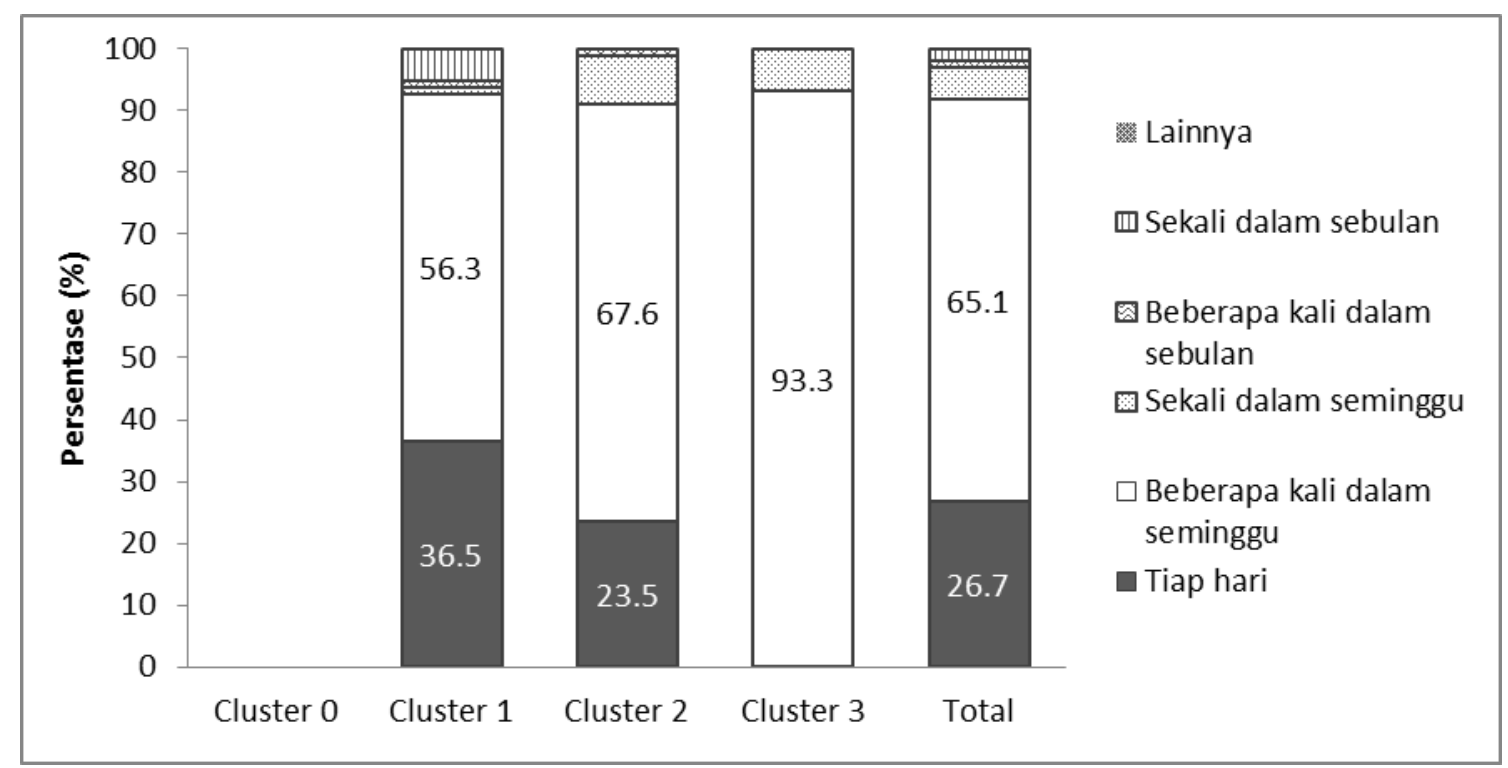

Gambar 4. Grafik Frekuensi Pengangkutan Sampah Oleh Petugas

Secara total, sebagian besar di Kabupaten Kudus, pengangkutan sampah oleh petugas dilakukan "beberapa kali dalam seminggu", sesuai pernyataan responden yaitu sebanyak $65,1 \%$. Selanjutnya diikuti oleh frekuensi "tiap hari”, sebanyak 26,7\%. Pengangkutan sampah oleh petugas yang dilakukan beberapa kali dalam seminggu, persentase tertinggi diberikan oleh cluster 3 , yaitu 93,3 \%. Pada cluster 0, tidak terdapat aktivitas pengangkutan sampah oleh petugas. e. Ketepatan Waktu Pengangkutan Sampah

Ketapatan waktu dalam pengangkutan sampah adalah faktor yang sangat penting dalam pengelolaan lingkungan. Keterlambatan pengangkutan sampah dapat menyebabkan penumpukan sampah pada pengumpulan sementara di tingkat rumah tangga, sehingga dapat berdampak pada banyaknya lalat, bau yang mengganggu, serta mengganggu kenyamanan lingkungan secara umum. 


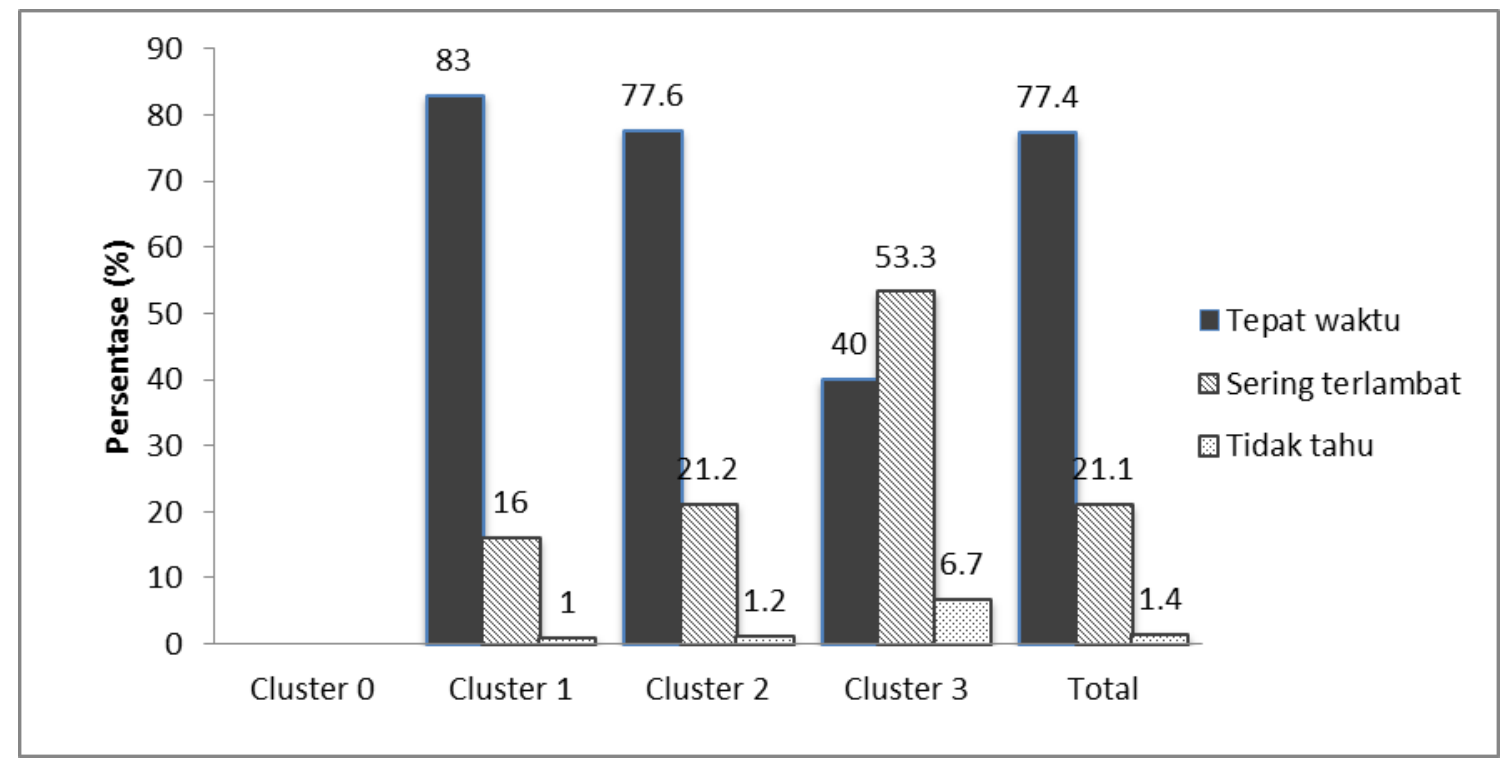

Gambar 5. Grafik Ketepatan Waktu Pengangkutan Sampah

Secara umum, sebagian besar responden di Kabupaten Kudus menyatakan bahwa pengangkutan sampah oleh petugas dilakukan tepat waktu, yaitu sebanyak $77,4 \%$. Ketepatan waktu tertinggi terdapat pada Desa/Kelurahan di cluster 1. Pada cluster 3 tampak bahwa sebagian besar responden menyatakan sering terlambat, yaitu sebanyak 53,3\%. Pada cluster 0 , tidak terdapat data karena tidak ada aktivitas pengangkutan sampah oleh petugas. f. Pembayaran Layanan Pengangkutan Sampah

Aktivitas pengangkutan sampah pada tingkat rumah tangga, umumnya dilakukan atas inisiatif dan swadaya masyarakat, sehingga biaya pengangkutan sampah dibayarkan oleh setiap rumah tangga. Pembayaran biaya pengangkutan sampah, selain sebagai upaya untuk meningkatkan partisipasi rumah tangga terhadap lingkungan, juga untuk menjaga kesinambungan layanan pengangkutan sampah. Pembayaran layanan pengangkutan sampah di Kabupaten Kudus, ditampilkan pada Gambar 6. 


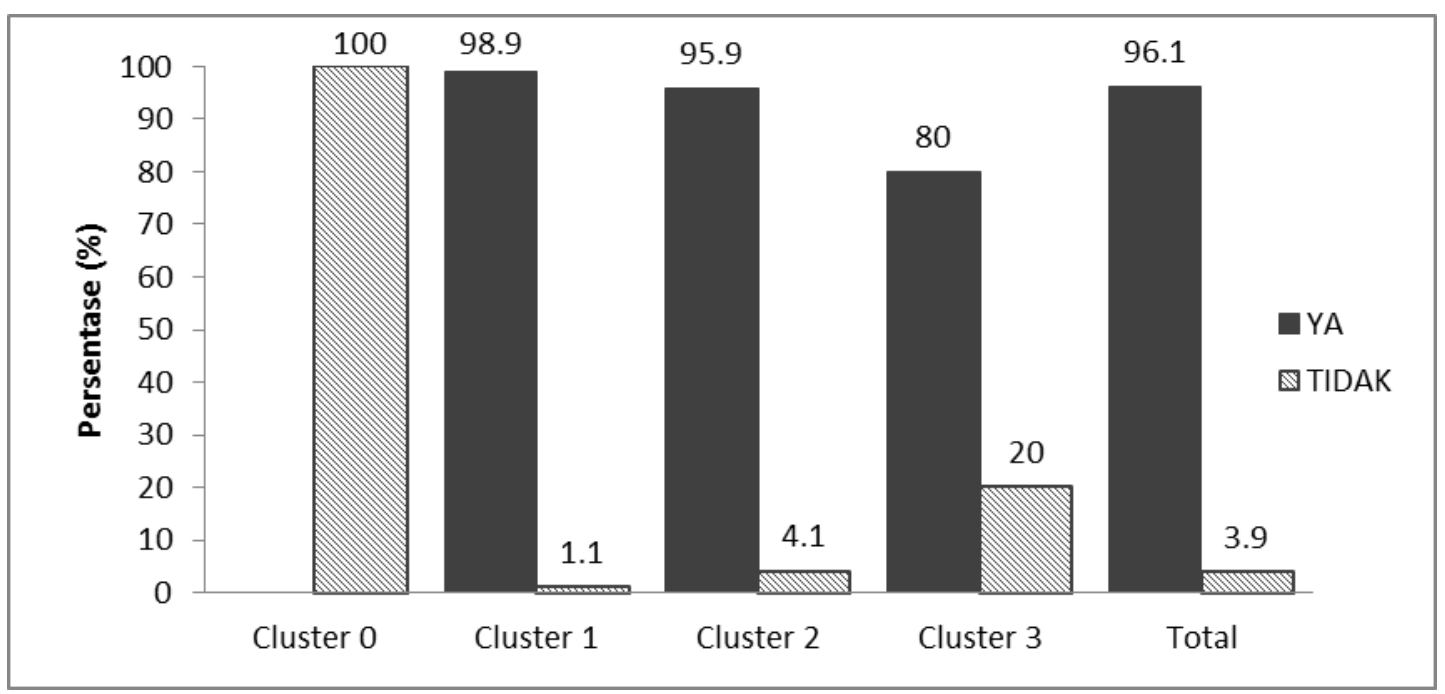

Gambar 6. Grafik Pembayaran Biaya Layanan Pengangkutan Sampah

Sebagian besar responden di Kabupaten Kudus melakukan pembayaran biaya layanan pengangkutan sampah, kecuali untuk cluster 0 , karena Desa/Kelurahan pada cluster 0 tidak terdapat aktivitas pengangkutan sampah. Pada cluster 3, tampak bahwa sebanyak $20 \%$ responden tidak melakukan pembayaran atas layanan pengangkutan sampah. Hal ini dapat diduga menjadi salah satu penyebab tingginya tingkat keterlambatan pengangkutan sampah pada cluster 3, seperti yang diberikan pada Gambar 5.

\section{KESIMPULAN}

Hanya sebagian kecil responden di Kabupaten Kudus yang melakukan pengelolaan sampah, yaitu 32,6\% (sebanyak 300 dari 920 responden). Responden pada cluster 0 belum melakukan pengelolaan sampah. Sedangkan responden yang melakukan pemilahan sampah sebelum dibuang, sebanyak 2,3 \% (sebanyak 7 respondendari 920 responden).

\section{DAFTAR PUSTAKA}

Aprilia, A., Tezuka, T. dan Spaargaren, G., 2012. Household Solid Waste Management in Jakarta, Indonesia: A Socio-Economic Evaluation, Waste Management - An Integrated Vision, Rabellon, M. L. F. (ed.), InTech.

Atalia, K. R., Buha, D. M., bhavsar, K. A. dan Shah, N. K., 2015. A review on compostingof municipal solid waste. IOSR Journal of Environmental Science, Toxicology and Food Technology, 9, Issue 5 Ver. 1: 20:29.

BPS Kabupaten Kudus, 2015. Kudus Dalam Angka 2015. Badan Pusat Statistik Kabupaten Kudus.

Chalam, Philippe and Catherine gaillochet, 2009. From waste to resources: World Waste Survey, Economica: Paris. 
Chung, S., dan Lo, C., 2008. Local waste management constraints and waste administrators in China. Journal of Waste Management, 28: 272 - 281.

Dionco-Adetayo, E., 2011. Guide to business research and thesis writing (2nd ed.). Ibadan, Nigeria: Rasmed publishers limited.

Guerrero, L. A., Maas, G. dan Hogland, W., 2013. Solid waste management challenges for cities in developing countries. Waste Management, 33: 220 - 232.

Jambeck, J. R., Geyer, R., Wilcox, C., Siegler, T. R., Perryman, M., Andrady, A., Narayan, R. dan Law, K. L., 2015. Plastic waste inputs from land into the ocean. Science, 347, Issue 6223: $768-771$.

Kardono, 2007. Integrated solid waste management in Indonesia. Proceedings of International Symposium on EcoTopia Science 2007, ISETS07: 629 - 633.

Kementerian Lingkungan Hidup (2008). Indonesian Domestic Solid Waste Statistics Year 2008. Kementerian Lingkungan Hidup Republik Indonesia.

Riswan., Henna R.S., Agus H., 2011, Pengelolaan Sampah Rumah Tangga di Kecamatan Daha Selatan, Jurnal Ilmu Lingkungan, Vol. 9(1):31-39.

Sujauddin, M., Huda, M.S., Rafiqul Hoque, A.T.M., 2008. Household solid waste characteristics and management in Chittagong, Bangladesh. Journal of Waste Management 28, 1688-1695.

Tobing, I. S. L., 2005. Dampak sampah terhadap kesehatan lingkungan dan manusia. Makalah pada Lokakarya "Aspek Lingkungan dan Legalitas Pembuangan Sampah serta Sosialisasi Pemanfaatan Sampah Organik sebagai Bahan Baku Pembuatan Kompos". Kerjasama Universitas Nasional dan Dikmenti, Jakarta.

USDP, 2014. Panduan Praktis Pelaksanaan EHRA (Environmental Health Risk Assessment / Penilaian Risiko Kesehatan karena Lingkungan). Urban Sanitation Development Program, Jakarta.

Vitor, F. M. C. B. S. dan Martinho, M. G. M., 2016. Factors influencing households' participation in organic waste separation. International Solid Waste Association. http://iswa.org.

Zhuang, Y., Wu, S. W., Wang, Y. L., Wu, W. Z. dan Chen, Y. X., 2008. Source separation of household waste: a case study in China. Journal of Waste Management, 28: 2022 - 2030. 